- модульність, наявність чітко визначеної навчальної мети, орієнтування на самонавчання, послідовність, інтерактивність, наявність елементів супроводу [2];

- зміст навчального матеріалу відповідатиме сучасним вимогам навчального процесу та сприятиме розвитку особистості [11].

Отже, використання електронних навчальних посібників дозволяє розв'язувати сучасні освітні завдання, а також забезпечує індивідуалізацію навчального процесу в початковій ланці освіти.

Вдало дібрані комп'ютерні програми забезпечують розвиток творчих здібностей, стимулюють пізнавальну активність, емоційну сферу школярів. Під час використання ЕНП у навчальному процесі початкової школи, необхідно враховувати їх відповідність індивідуальним особливостям молодших школярів і специфіку конкретних навчальних предметів.

\title{
Література
}

1. Агеев В. Н. Электронние издания учебного назначения. Концепции, создание, использование: [учеб. пособ.] / В. Н. Агеев, Ю. Г. Древс. - М.: МГУП, 2003. - 236 с. 2. Бейлинсон В. Г. Характеристика, подготовка, конструирование учебных изданий / В. Г. Бейлинсон. - М.: Арсенал образования, 2006. 286 с. 3. Беспалько В. П. Теория учебника: Дидактический аспект / В. П. Беспалько. - М. : Педагогика, 2008. - 160 с. 4. Воронина Т. П. Образование в эпоху новых информационных технологий / Т. П. Воронина, В. П. Кашицин, О. П. Молчанова. - М. : Информатика, 1995. -220 с. 5. Зуев Д. Д. Школьный учебник / Д. Д. Зуев. - М. : Педагогика, 1999. - 240 с. 6. Краевский В. В. Дидактические основания определения содержания учебника / В. В. Краевский, И. Я. Лернер // Проблемы школьного учебника. - Вып. 8. - М. : Просвещение, 2003. - 305 с. 7. Крук Б. И. Электронный учебник как средство субъектно-объектного инфовзаимодействия в процессе обучения: проблемы инфовзаимодействия / Б. И. Крук, О. Б. Журавлева, И. В. Калачев. - Новосибирск. - Вып. 2. - 2000. -189 с. 8. Лернер И. Я. Методологические проблемы дидактической теории построения учебника / Каким быть учебнику: Дидактические принципы построения / И. Я. Лернер. - Ч. 1. - М. : Просвещение, 1999. - 197 с. 9. Носкова Т. Н. Аудиовизуальные технологии в образовании / Т. Н. Носкова. - СПб. : СПбГУ- КиТ, 2004.- 99 с. 10. Родин В. П. Создание электронного учебника: концепция и способ реализации: [учеб. издание] / В. П. Родин. - М. : Венец, 2008. - 31 с. 11. Тоискин В. С. Теоретические основы разработки электронных образовательных изданий (антропологический подход): [учеб. пособ.] / В. С. Тоискин, В. В. Красильников. - Ставрополь : СГПИ, 2010. - 108 с.

УДК 37.091.212.7:004.4

Надія Олефіренко

\section{ВИКОРИСТАННЯ ЕЛЕКТРОННИХ ДИДАКТИЧНИХ РЕСУРСІВ ДЛЯ ЗАКЛАДАННЯ ОСНОВ УСПІШНОСТІ МОЛОДШОГО ШКОЛЯРА В ПОДАЛЬШОМУ НАВЧАННІ}

Олефіренко Н. В. Використання електронних дидактичних ресурсів для закладання основ успішності молодшого школяра в подальшому навчанні.

У статті виокремлено низку функцій електронних дидактичних ресурсів, спрямованих на закладання основ успішності подальшого навчання молодшого школяра. Наведено характеристику інструментальної, дослідницької функцій, функції розвитку інтелектуальних умінь молодшого школяра, мобілізаційної функції та функції сприяння формуванню цілісного світогляду.

Ключові слова: молодший школяр, електронні дидактичні ресурси, функції.

Олефиренко Н. В. Использование электронных дидактических ресурсов для закладывания основ успешности младшего школьника в дальнейшем обучении.

В статье выделен ряд функций электронных дидактических ресурсов, направленных на закладывание основ успешности дальнейшего обучения младшего школьника. Приведена характеристика инструментальной, исследовательской функций, функции развития интеллектуальных умений младшего школьника, мобилизационной функции и функции содействия формированию целостного мировоззрения.

Ключевые слова: младший школьник, электронные дидактические ресурсы, функции.

Olefirenko N. V. Using of electronic teaching resources for success of primary school children in further education.

In the article is defined a number of electronic teaching resource's functions for further success training of young pupil. It is given a characteristic of the instrumental and research functions, function 
of the development intellectual skills of primary school children, mobilization function and the function of promotion holistic worldview.

Key words: primary school children, electronic teaching resources, functions.

Використання електронних дидактичних ресурсів у початковій школі відрізняється певною специфікою: воно потребує педагогічного обгрунтування, чіткої спланованості, виваженості й обережності, точного добору засобів як з позиції сприяння досягненню поставленої дидактичної мети, так і з позиції врахування індивідуальних навчальних можливостей і потреб учнів. Окреслена специфіка актуалізує проведення досліджень, спрямованих на розроблення наукових засад ефективного використання електронних дидактичних засобів у початковій школі.

Проблеми використання електронних ресурсів у навчанні молодших школярів достатньо широко обговорюються у психолого-педагогічній літературі. Зокрема, питанням застосування комп'ютера у процесі викладання окремих дисциплін початкової школи присвячено праці, Д. Зарецького, 3. Зарецької, Ю. Первіна, Н. Федянінової, М. Цвєткової, В. Шакотько та інших. У дослідженнях П. Бісіркіна, Ю. Жука, Н. Толяренко розглядається вплив комп'ютерних засобів навчання на індивідуальні особливості молодших школярів. Водночас у педагогічній літературі не знайшли достатнього розкриття питання запровадження продуктивних підходів до реалізації дидактичного потенціалу електронних ресурсів у навчальному процесі початкової школи, що передбачає проведення теоретичних досліджень, спрямованих на з'ясування сутності функцій таких ресурсів у навчанні молодших школярів.

Здійснений аналіз психолого-педагогічної літератури з практики застосування електронних дидактичних ресурсів та проблем їх розроблення дав змогу виявити спектр основних функцій цих ресурсів у навчанні молодших школярів [2; 3]. Окрім функцій, що сприяють формуванню позитивного ставлення дитини до процесу і результату навчання (розвитку власних мотивів школяра до виконання навчальних дій, відслідковування і схвалення успішних дій учня, створення сприятливого емоційного фону, реалізації зв'язку змісту навчання 3 життям), функцій, що забезпечують успішність школяра в засвоєнні змісту навчання (візуалізації, тренінгову, корекції набутих знань й умінь, інтеграційну, адаптаційну, забезпечення своєчасної допомоги в опануванні змісту навчання, компенсаторну) та функцій оптимізації навчального процесу (контрольна, діагностувальна, моніторингова, інтенсифікації навчального процесу) вважаємо важливим виокремити функції, зорієнтовані на закладання основ успішності подальшого навчання школяра. Ця група охоплює функції, які $є$ важливими для поточного навчального процесу, але мають перспективний характер і сприяють становленню пізнавальної діяльності школяра - інструментальна, дослідницька, розвитку інтелектуальних умінь, мобілізаційна, сприяння формуванню цілісного світогляду.

Метою статті $є$ характеристика функцій електронних дидактичних ресурсів, які зорієнтовані на закладання основ успішності молодшого школяра в подальшому навчанні.

Інструментальна функиія. Початкова школа є тим етапом, коли комп'ютер перестає бути виключно засобом розваги, а перетворюється на інструмент його предметної, творчої діяльності. У такому перетворенні провідну роль відіграє систематичне використання електронних дидактичних засобів у шкільному навчанні.

У процесі застосування таких засобів школяр оволодіває стандартними інструментами управління програмним засобом (стандартними пристроями, інтерфейсними елементами; способами отримання допомоги), опановує новий інструментарій предметної діяльності (комп'ютерні інструменти художньої творчості - масштабування, інструменти роботи 3 кольором, інструменти створення спецефектів тощо; пристрої віртуальної реальності джойстрінг, інтерфейс-рукавички; інструменти дослідження - мікроскоп, телескоп, геосервісні інструменти; комп'ютерні інструменти вимірювання - годинник, лінійка, транспортир); набуває початкових навичок використання основних інструментів масових цифрових технологій (комп'ютерних інструментів роботи 3 текстами й рисунками; інструментів оброблення аудіо-, фото, відеозаписів; інструментів подання та відображення інформації у вигляді діаграм, гістограм, ментальних карт тощо; інструментів створення власних електронних матеріалів - презентацій, оформлених вітальних листівок, творів).

Для формування інструментальних умінь молодших школярів важливо поряд зі звичайними програмними засобами, призначеними для предметного навчання, 
використовувати програми, які відносяться до універсальних засобів масового призначення, i використовувати реальні програмні продукти, а не їх емулятори. Під час відбору засобів предметного навчання слід звертати увагу на дотримання усталених стандартів в організації інтерфейсу та використання інструментів. Стосовно програмних засобів універсального призначення, то доцільність їх використання зумовлена продуманістю представлення їх функціональних можливостей - найбільш уживані функції зібрані окремо і $\epsilon$ легко доступними, функції, що використовуються рідше - потребують вибору додаткових вкладинок, вікон або пунктів меню. Це дозволяє дитині опановувати такі програмні засобами з різною глибиною, поступово оволодіваючи всім багатством закладених можливостей. Окрім того, така надлишковість функціональних можливостей спонукає школяра до самостійного вивчення призначення інструментів.

Під час роботи молодшого школяра 3 програмними засобами універсального призначення, слід звернути увагу на використання інтегрованості цих засобів і сформувати уміння зв'язування документів, створених у різних середовищах, перенесення об'єктів 3 одного середовища в інше. Наприклад, для підготовки презентації дитина може скористатися текстовими фрагментами, підготовленими за допомогою текстового процесора, діаграмами, створеними у середовищі електронних таблиць, малюнками, підготованими у середовищі відповідного графічного редактора. Використання засобів інтеграції молодшими школярами $\epsilon$ важливим для підвищення ефективності навчання в майбутньому.

Дослідницька функція. Можливість і необхідність дослідницької діяльності молодших школярів обгрунтовано в численних педагогічних та психологічних працях Т. Байбари, В. Давидова, Д. Ельконіна, Г. Костюка, І. Лернера, О. Савченко тощо. Молодші школярі здатні залучаться до пошукової діяльності, застосовувати засвоєні знання і способи діяльності в нових ситуаціях і самостійно проводити дослідження на доступному їм рівні [1].

Залучення дитини до дослідницької діяльності цілком відповідає ії віковим потребам, оскільки в цьому віці ще зберігається природна допитливість і цікавість дитини, дитина багато експериментує й відкриває для себе правила й закони. У цьому зв'язку перед школою постає дуже важливе завдання збереження й розвитку допитливості, інтересу, бажання пізнати й краще розібратися в побудові об'єктів реального світу, у перебігу природних процесів, змін у природі й суспільстві. Залученню молодшого школяра до дослідницької діяльності сприяють і наявність книжок, зорієнтованих на пробудження допитливості, доступність іграшок-приборів, іграшок-трансформерів, у тому числі в комп'ютерній реалізації.

Визначимо особливості педагогічних програмних середовищ, які сприяють залученню молодших школярів до дослідницької діяльності:

Педагогічні програмні засоби надають змогу вільно маніпулювати 3 різноманітними об'єктами на екрані комп'ютера. У процесі маніпуляції учень на екрані виконує дії з об'єктами, повертає в початкове положення, скасовує дії, повторює дії тощо, змінює вихідні дані. Наявність таких можливості спонукає школяра до активних дій, що дозволяє не тільки задовольнити його експериментування. Окрім того, можливість маніпулювати з різноманітними об'єктами на екрані дозволяє розвивати в молодшого школяра здатність осмислювати свою навчальну діяльність. Він може, задаючи поведінку об'єкта й обмірковуючи його реакцію, осмислювати свої кроки до здійснення наміру. Учень навчається керувати процесом навчання: ставити собі задачу й знаходити шляхи iї розв'язання. За допомогою комп'ютера він може проводити різні експерименти, повторюючи імітацію до тих пір, поки не буде досягнутий бажаний результат.

Електронні ресурси навчального призначення, орієнтовані на молодших школярів, можуть провокувати школяра на самостійне відкриття загальних правил із часткових, формулювання висновків із ситуацій. Наприклад, у межах середовища GeoGebra учні можуть експериментувати з такими інтерактивними моделями, які забезпечать покроковий супровід i спонукатимуть до самостійного формулювання узагальнень і висновків.

Розвиток інтелектуальних умінь. Проблеми інтелектуального розвитку школярів у процесі навчання розглядаються в працях Г. Батуріної, М. Данилова, А. Дмитрієва, Б. Осипова, І. Звєрева, В. Краєвського, В. Кулько, І. Лернера, В. Лозової, В. Орлова, М. Скаткіна, А. Усової, В. Цетлін, Т. Цехмістрової, Н. Чутко, Т. Шамової, Г. Щукіної, І. Якиманської та ін. Одним із найважливіших результатів проведених досліджень $\epsilon$ висновок про те, що особливе значення має надаватися інтелектуальному розвитку учнів молодшого шкільного віку, тому що саме на 
цей період припадає формування основних логічних структур мислення та інтелектуальних умінь дитини - фундаменту іiі успішного навчання і розвитку в подальші роки [5].

У психолого-педагогічних дослідженнях констатовано неоднозначність у тлумаченні сутності інтелектуальних умінь та їх компонентів, висловлюються різні думки щодо структурних компонентів інтелектуальних умінь. Грунтуючись на роботах Ю. Бабанського, А. Дмитрієва, В. Паламарчука, В. Сластьоніна, Л. Царенко, присвячених формуванню у школярів інтелектуальних умінь, у нашій роботі розглядатимемо вплив електронних дидактичних ресурсів на розвиток таких інтелектуальних умінь: знаходити потрібну інформацію в різних джерелах; сприймати інформацію; логічно осмислювати матеріал, виокремлювати в ньому головне; здійснювати загальні логічні прийоми мислення (порівнювати, аналізувати, класифікувати, систематизувати, узагальнювати, доводити тощо); застосовувати інструментарій для підготовки та отримання інформації; розв'зувати проблемні пізнавальні задачі.

Формування інтелектуальних умінь молодших школярів здійснюється під час їхньої діяльності з електронними дидактичними ресурсами за рахунок:

- складності комп'ютерних інструментів, якими учень оволодіває під час роботи із програмним засобом. Інструментарій, яким оволодіває учень, потребує розуміння символьних позначень, співвіднесення власних рухів щодо переміщення миші або джойстика зі змінами, які відбуваються на екрані комп'ютера, розуміння технології виконання дій з різними об'єктами щоб вказати на об'єкт, потрібно натиснути ліву кнопку миші, щоб перетягнути - переміщувати мишу з одночасним утриманням лівої кнопки миші, вибрати новий режим - двічі клацнути тощо;

- занурення школяра в інформаційно-насичене середовище, яке пропонує не єдиний набір правил, є надлишкову інформацію, розмаїття думок, підходів до вивчення об'єкта або процесу. Як зазначає М. Варшауер, [6] інформаційно-насичене середовище зорієнтовує школяра на формулювання питань і пошук відповідей на ці запитання [6];

- нестандартності й різноманітності ситуацій, у які занурюється учень під час роботи 3 електронними ресурсами. Змінення сюжетного оформлення, наявність додаткових стимулів (можливість виграти приз або навпаки, програти), поява незапланованих труднощів створює для школяра нові умови, у які він повинен переносити набуті знання й уміння. В нових умовах учень навчається швидко сприймати інформацію й аналізувати ситуацію, планувати подальші власні дії, порівнювати наявний досвід і визначати достатність або недостатність набутих знань. Через те, що у програмах, орієнтованих на молодших школярів, нестандартні ситуації пов'язані з ігровим забарвленням, інтелектуальна діяльність учня $\epsilon$ цілком природною;

- необхідності аналізу ситуацій, які виникають, і прийняття рішення щодо вибору подальших дій. Зокрема, незважаючи на супровід дитини допомогою під час роботи 3 програмним засобом, школяр часто змушений самостійно робити вибір - вибрати правильну відповідь, шлях проходження гри, рівень складності завдань і рівень допомоги. Необхідність здійснення аналізу ситуації і прийняття рішення стимулює розвиток мислення й аналітичних умінь.

Мобілізаційна функиія. Одними із важливим характеристик якості знань школярів $\epsilon$ оперативність і гнучкість знань, які передбачають готовність школяра до використання набутих знань, умінь і навичок у різноманітних ситуаціях. Поняття оперативності і гнучкості як характеристик якості знань пов'язані з поняттям мобілізації знань, яке розуміється нами як активізація знань, умінь і навичок для успішної діяльності школяра в конкретній типовій або нетиповій ситуації.

Застосування електронних дидактичних ресурсів сприяє мобілізації знань, умінь і навичок школярів за рахунок:

1. Розмаїття ситуацій використання набутих знань, умінь та навичок. Розмаїття ситуацій забезпечується варіативністю сюжетного оформлення завдань та ігровим забарвленням завдань. Ситуації, в які занурюється учень під час використання електронних дидактичних ресурсів, динамічно змінюються, часто $є$ несподіваними для школяра і потребують швидкої реакції, нестандартної поведінки, комбінування раніше вивчених способів дій.

2. Наявності змагального складника, що стимулює школяра до мобілізації знань для отримання кращих результатів порівняно з іншими користувачами або порівняно з власними попередніми результатами. 
3. Моментальної реакції програмного засобу на дії користувача, що дозволяє школяреві оперативно змінювати обраний спосіб рішення, переорієнтація з одного способу рішення на інший, здійснювати інші спроби у пошуку правильного розв'язку завдання.

Функиія формування иілісного світогляду. Світогляд ставносить систему принципів, поглядів, цінностей, ідеалів, які визначають ставлення дитини до дійсності, загальне розуміння світу, життєві позиції [4]. Формуванню цілісного світогляду учня у процесі використання електронних дидактичних ресурсів сприяе те, що сучасні цифрові технології здатні створити на екрані комп'ютера реалістичне подання тих об'єктів, що вивчаються, забезпечуючи їх візуальне, аудіальне і навіть тактильне сприйняття дитиною і тим самим надаючи їй змогу отримати реальні відчуття зіткнення 3 навколишнім світом. Зокрема, дитина може бачити повнокольорові фотографії й відеозаписи об'єктів, сприймати об'ємність об'єктів, чути записи реальних звуків природи, відчувати об'єкти на дотик. Додаткові уявлення про мікрооб'єкти школяр може отримати за рахунок їх кількаразового збільшення зі збереженням якості зображення.

Становленню гуманістичних позицій учня сприяє те, що в програмних засобах для дітей молодшого шкільного віку використовуються так звані «педагогічні агенти», які оточують дитину у віртуальному світі і завжди готові прийти ій на допомогу. Вони наділені терпимістю, привітністю, чуйністю, і школяр сприймає норми тактовних, коректних, доброзичливих взаємин.

Робота з програмними засобами формує світовідчуття і світовідношення школяра за допомогою сюжетного характеру тих навчальних завдань, які ставляться перед ним. Ці завдання пов'язані із гуманними, творчими цілями - допомогти герою врятувати принцесу, знайти ключ, досягти іншої планети, побудувати будинок тощо. У середовищі педагогічного програмного засобу школяр не стикається з агресією у будь-яких іiї виявленнях, тут панує верховенство добра, утвердження загальнолюдських цінностей.

Використання електронних дидактичних ресурсів допомагає налаштовувати школяра на активність у пізнанні світу. Він не $є$ пасивним читачем навчальних текстів, від нього очікуються активні дії - наприклад, зміною розмірів фігури досягти ії певних властивостей, вибрати оптимальну точку спостереження за планетою, перемістити тварину у зручне для неї середовище тощо. Діяльність школяра спрямовується не тільки на досягнення навчальних цілей, а водночас і на формування його поваги й дбайливого ставлення до природи, до навколишнього світу.

Отже, у практиці початкової освіти електронні дидактичні ресурси мають потужний потенціал для закладання основ успішності учня в подальшому навчанні. Цьому сприяють такі функції електронних ресурсів, як інструментальна, дослідницька, розвитку інтелектуальних умінь, мобілізаційна, сприяння формуванню цілісного світогляду. Перспективними напрямами подальших досліджень, на нашу думку, є розроблення педагогічних технологій застосування електронних ресурсів певного функціонального спрямування у навчанні молодших школярів.

\section{Література}

1. Байбара Т. М. Формування у молодших школярів дослідницьких умінь / Т. М. Байбара // Навчання і виховання учнів 2 класу: [метод. посіб. для вчит.] / упор. О. Я. Савченко. - К.: Початкова школа, 2003. - С. 69-86. 2. Белоусова Л. И. Дидактический потенциал цифровых образовательных ресурсов для младших школьников / Л. И. Белоусова, Н.В.Олефиренко // Международный электронный журнал «Образовательные технологии и общество» - 2013. - V. 16. - №1. - С. 586-598. Режим доступу: http://ifets.ieee.org/russian/ depository/v16_i1/ html/14.htm 3. Білоусова Л. I. Роль електронних дидактичних ресурсів у забезпеченні успішності засвоєння змісту навчання учнями початкової школи / Л. І. Білоусова, Н.В.Олефіренко // Обрії. - 2012. - № 2. - С.99-103. 4. Подольська Є. А. Філософія: [підручник] / С. А. Подольська. - К. : Центр навч. літератури, 2006. 704 с. 5. Толяренко Н. І. Фактори, які зумовлюють доцільність використання комп'ютера для формування інтелектуальних умінь учнів початкової школи / Н. І. Толяренко // Вісник Харківського національного педагогічного університету імені Г. С. Сковороди. Серія: Психологія. - Вип. 33. 2010. - C. 22-26. 6. Warschauer M. Laptops and Literacy: Learning in the Wireless Classroom / M.Warschauer. - New York: Teachers College Press, 2006. - 192 p. 